\title{
HUBUNGAN PENGETAHUAN TALASEMIA DENGAN KEPATUHAN KELUARGA MEMBAWA ANAK MENJALANI TRANFUSI DARAH
}

\author{
THALASSEMIA RELATIONSHIP WITH KNOWLEDGE OF COMPLIANCE \\ BRING THE FAMILY CHILDREN UNDERGOING BLOOD TRANSFUSION
}

\author{
${ }^{1}$ Vitayoni Oktaria, Desi Kurniawati ${ }^{2}$ \\ ${ }^{1}$ STIKes Muhammadiyah Pringsewu \\ ${ }^{2}$ RSUD Pringsewu \\ Email: desi_kurniawati04@yahoo.com
}

\begin{abstract}
Abstrack thalassemia relationship with knowledge of compliance Bring the family children undergoing blood transfusion. Thalassemia is a chronic disease that is genetically inherited, which causes the body can not make normal red blood cells so that the red blood cells are easily damaged and aged less than 120 days, resulting in anemia. The purpose of this study is todetermine whether there is a relationship between knowledge with adherence families bring children with thalassemia carries blood transfusion therapy. The subject of this study is a family of children with Thalassemia in hospitals Pringsewu. This study design is a correlation study, with cross sectional method. Sampling using purposive sampling technique, the amount of sample of 58 respondents, data retrieval is using questionnaire to determine the level of knowledge and observation data by looking at the data visit families of children with Thalassemia is a blood transfusion. The results of data analysis using chi square obtained their. Thalassemia knowledge compliance relationship with the family to bring the child to undergo blood transfusions in hospitals Pringsewu. Natural implement care to children with thalassemia, in order to be thorough to patients with thalassemia children and to families by providing education, information, emotional support so that compliance with the family to bring the child to be maximal blood transfusion.
\end{abstract}

\begin{abstract}
Abstrak Hubungan Pengetahuan Talasemia Dengan Kepatuhan Keluarga Membawa Anak Menjalani Tranfusi Darah. Thalassemia penyakit menahun yang diturunkan secara genetik, yang menyebabkan tubuh tidak dapat membentuk sel darah merah yang normal sehingga sel darah merah mudah rusak dan berumur kurang dari 120 hari sehingga mengakibatkan anemia. Tujuan penelitian ini adalah untuk mengetahui apakah ada hubungan antara pengetahuan dengan kepatuhan keluarga membawa anak dengan thalassemia membawa terapi transfusi darah. Subyek penelitian ini adalah keluarga anak dengan Thalassemia di RSUD Pringsewu. Desain penelitian ini adalah studi korelasi, dengan metode cross sectional. Pengambilan sampel menggunakan teknik Purposive Sampling, jumlah sampel 58 responden, pengambilan data menggunakan kuisioner untuk mengetahui tingkat pengetahuan dan yang kedua teknik observasi data dengan melihat data kunjungan keluarga anak penderita Talasemia melakukan transfusi darah. Hasil analisa data menggunakan chi square didapatkan adanya hubungan pengetahuan Thalassemia dengan kepatuhan keluarga membawa anak menjalani transfusi darah. Dalam melaksanakan perawatan kepada anak penderita Thalassemia, agar dilakukan secara menyeluruh kepada pasien anak Thalassemia dan kepada keluarga melalui pemberian edukasi, informasi, dukungan emosional sehingga kepatuhan keluarga untuk membawa anak untuk transfusi darah menjadi lebih maksimal.
\end{abstract}

Kata Kunci : Thalassemia, Pengetahuan, Kepatuhan. 


\section{PENDAHULUAN}

Penyakit kronik yang banyak terjadi pada anak-anak di Indonesia adalah penyakit thalasemia. Thalasemia merupakan penyakit kronik yang diturunkan secara autosomal resesif dari orang tua kepada anaknya yang disebabkan oleh defisiensi sintesis rantai polipeptida yang mempengaruhi sumsum tulang produksi hemoglobin dengan manifestasi klinis anemia berat (Potts \& Mendleco, 2007) dalam Dahnil, et.al, 2017). Tubuh tidak dapat membentuk sel darah merah yang normal, sehingga sel darah merah mudah rusak atau berumur pendek kurang dari 120 hari dan terjadilah anemia (Rachmaniah, 2012). Anak yang menderita thalasemia dapat mengalami anemia berat ataupun ringan. Hal ini dikarenakan rendahnya jumlah sel darah merah atau tidak cukupnya hemoglobin pada sel darah merah (Sembiring, 2010).

Seorang penderita thalasemia harus melalui serangkaian bentuk perawatan medis. Salah satu pengobatan yang tepat untuk penderita thalasemia adalah dengan melakukan transfusi darah dan suntikan desferal secara rutin. Pada penderita thalasemia akut akan tergantung pada transfusi darah serta desferal seumur hidup (Pratiwi, 2017).

Keberhasilan menjalankan pengobatan tidak hanya di tentukan oleh diagnosis dan pemilihan obat yang tepat tetapi juga kepatuhan dalam menjalankan pengobatan. Kepatuhan merupakan kunci utama dalam melakukan rutinitas transfusi pada pasien thalasemia untuk menjaga daya tahan tubuh anak dengan thalasemia. Beberapa upaya sudah dilakukan seperti memberikan penyuluhan kepada orang tua yang mempunyai anak thalasemia agar patuh dalam membawa anaknya untuk diberikan terapi (Rahayu et. al, 2015).

Banyak faktor yang menjadi pemicu kurang patuhnya terapi pada anak thalasemi, yaitu pengetahuan yang merupakan faktor yang penting dan sangat mempengaruhi kepatuhan terapi pada anak thalasemia. Selain itu, kepatuhan mengantarkan anak untuk menjalani segala terapi pengobatan thalassemia.Tindakan perawatan paling penting yang harus didapatkan oleh seorang anak adalah transfusi darah.Transfusi darah harus dilakukan rutin setiap 3 minggu untuk mempertahankan $\mathrm{Hb}$ dan keadaan fisik penderita (Hockenberry MJ \& Wilson D. 2009).
Berdasarkan hasil studi pendahuluan dengan cara melakukan wawancara terhadap keluarga pasien thalasemia di Ruang Anak RSUD Pringsewu, terdapat 8 pasien anak dengan thalasemia yang tidak rutin melakukan kunjungan sesuai jadwal ke Rumah Sakit Umum Daerah Pringsewu untuk melakukan transfusi darah sehingga mereka datang dengan $\mathrm{Hb}$ yang terlalu rendah. Keluarga menganggap bahwa anaknya masih sehat pada saat jadwal kunjungan.Dengan kejadian tersebut penulis tertarik untuk melakukan penelitian tentang "hubungan pengetahuan Thalassemia dengan kepatuhan keluarga membawa anak menjalani transfusi darah di Rumah Sakit Umum Daerah Pringsewu Tahun 2019”.

\section{METODE}

Desain penelitian ini adalah studi korelasi (correlation study) dengan menggunakan pendekatan cross sectional. Penelitian dilakukan di RSUD Pringsewu pada bulan Mei-Juni 2019. Subyek penelitian ini adalah keluarga anak dengan Thalassemia di RSUD Pringsewu. Pengambilan sampel menggunakan teknik Purposive Sampling, jumlah sampel 58 responden, pengambilan data menggunakan kuisioner untuk mengetahui tingkat pengetahuan dan observasi data dengan melihat data kunjungan keluarga anak penderita Talasemia melakukan transfusi darah dan analisa data menggunakan chi square.

\section{HASIL}

Hasil penelitian disajikan dalam bentuk grafik, tabel, atau deskriptif. Hasil tidak mendiskripsikan pengulangan metodologi dan konten pada pembahasan. Hindari duplikasi data dari tabel figure. Analisis dan interpretasi hasil ini diperlukan sebelum dibahas.

Tabel dituliskan di tengah atau di akhir setiap teks deskripsi hasil/perolehan penelitian. Bila lebar Tabel tidak cukup ditulis dalam setengah halaman, maka dapat ditulis satu halaman penuh. Judul Tabel ditulis dari kiri, bila judul tabel lebih dari dua baris, maka baris kedua menjorok ke dalam., dan dituliskan dalam spasi tunggal. Semua kata diawali huruf besar, kecuali kata sambung, sebagai contoh, dapat dilihat Tabel 1. 
Tabel 1. Distribusi Frekuensi Berdasarkan Umur, Jenis Kelamin, Pendidikan dan Pekerjaan

\begin{tabular}{lcc}
\hline \multicolumn{1}{c}{ Variabel } & Frequensi & $\begin{array}{c}\text { Persentase } \\
(\%)\end{array}$ \\
\hline $\begin{array}{l}\text { Dewasa Muda } \\
\text { (18-25 th) }\end{array}$ & 3 & \\
$\begin{array}{l}\text { Dewasa Awal } \\
\text { (26-40 th) }\end{array}$ & 40 & $4,4 \%$ \\
Dewasa Pertengahan & 25 & $58,8 \%$ \\
(41-65 th) & & $36,8 \%$ \\
Laki-laki & 29 & $42,6 \%$ \\
Perempuan & 39 & $57,4 \%$ \\
Dasar & 40 & $58,8 \%$ \\
Menengah & 26 & $38,2 \%$ \\
Tinggi & 2 & $2,9 \%$ \\
Ibu Rumah Tangga & 24 & $35,3 \%$ \\
Buruh & 8 & $11,8 \%$ \\
Tani & 21 & $30,9 \%$ \\
Wiraswasta & 15 & $22,1 \%$ \\
Total & 68 & $100 \%$ \\
\hline
\end{tabular}

* Sumber data: RSUD Pringsewu tahun 2019

Berdasarkan tabel 1 distribusi frekuensi umur sebagian besar responden termasuk dalam dewasa awal, jenis kelamin sebagian besar permpuan, pendidikan sebagian besar pendidikan dasar dan sebagian besar responden adalah ibu rumah tangga. .

\begin{tabular}{|c|c|c|c|c|c|c|c|}
\hline \multirow{3}{*}{$\begin{array}{l}\text { Tabel } \\
\begin{array}{c}\text { Peng } \\
\text { etahu } \\
\text { an }\end{array}\end{array}$} & \multicolumn{3}{|c|}{$\begin{array}{l}\text { 1. Hubungan } \\
\text { Thalassemia } \\
\text { Keluarga } \\
\text { Transfusi Dar }\end{array}$} & \multicolumn{2}{|c|}{$\begin{array}{l}\text { Tingkat } \\
\text { dengan } \\
\text { Membawa } \\
\text { ah }\end{array}$} & \multicolumn{2}{|c|}{$\begin{array}{r}\text { Pengetahuan } \\
\text { Kepatuhan } \\
\text { Anaknya }\end{array}$} \\
\hline & \multicolumn{4}{|c|}{ Kepatuhan } & \multicolumn{2}{|c|}{ Total } & P- OR \\
\hline & $\begin{array}{l}\text { Tidak } \\
\text { Patuh }\end{array}$ & $\begin{array}{l}\text { Pat } \\
\text { uh }\end{array}$ & & & & & \\
\hline & $\mathbf{N}$ & $\%$ & $\mathbf{N}$ & $\%$ & $\mathbf{N}$ & $\%$ & \\
\hline $\begin{array}{l}\text { Kura } \\
\text { ng } \\
\text { Baik }\end{array}$ & $\begin{array}{c}17 \\
5\end{array}$ & $\begin{array}{l}25 \\
7,4\end{array}$ & $\begin{array}{l}15 \\
31\end{array}$ & $\begin{array}{l}22,1 \\
45,5\end{array}$ & $\begin{array}{l}32 \\
36\end{array}$ & $\begin{array}{l}47,1 \\
52,9\end{array}$ & $\begin{array}{cc}0,00 & 7,01 \\
1\end{array}$ \\
\hline Total & 22 & 32,4 & 46 & 67,6 & 68 & 100 & \\
\hline
\end{tabular}

Hasil Penelitian menunjukkan bahwa dari 32 responden dengan pengetahuan kurang sebanyak 15 responden (22\%) tidak patuh membawa anaknya untuk transfusi darah, 17 responden $(22 \%)$ patuh membawa anaknya untuk transfusi darah. Sedangkan dari dari 36 dengan pengetahuan baik 4 responden yang tidak tidak patuh membawa anaknya untuk transfusi darah, dan 32 responden patuh membawa anaknya untuk transfusi darah. Hasil uji statistik menunjukkan bahwa nilai $p$ - value $=0,001$ $(<0,05)$ yang artinya terdapat hubungan yang bermakna antara Tingkat Pengetahuan
Thalassemia dengan Kepatuhan Keluarga Membawa Anaknya Transfusi Darah Di RSUD Pringsewu Tahun 2019 dengan nilai odd ratio $(\mathrm{OR}=7,010)$ yang artinya responden dengan pengetahuan kurang akan beresiko 7 kali tidak patuh membawa anaknya untuk transfusi darah.

\section{PEMBAHASAN}

Dari hasil analisis didapatkan bahwa sebagian besar responden keluarga dengan anak Thalassemia di RSUD Pringsewu tahun 2019 memiliki tingkat pengetahuan baik sebanyak 36 responden (52,9\%). Pengetahuan sangat diperlukan agar terbentuk tindakan atau perilaku positif yang berlangsung lama.Pengetahuan atau kognitif merupakan domain yang sangat penting untuk terbentuknya tindakan seseorang. Sejalan dengan pendapat peneliti, Notoatmodjo (2010) menjelaskan pengetahuan adalah hasil penginderaan manusia, atau hasil tahu seseorang terhadap objek melalui indra yang dimilikinya (mata, hidung, telinga dan sebagainya).

Pengetahuan yang baik mengenai thalassemia dapat dipengaruhi oleh usia, tingkat pendidikan, pekerjaaan dan media informasi. Salah satu faktor yang mempengaruhi pengetahuan baik adalah usia. Dalam penelitian ini menunjukkan responden dengan usia dewasa awal (26-45 tahun) sebesar 61,8\%. Sedangkan responden yang berpengetahuan baik sebesar 52,9\%. Menurut Marnis, D., Indriati, G., \& Nauli, F. A. (2018 )semakin bertambahnya usia seseorang maka tingkat pengetahuan seseorang akan bertambah seiring pengalaman hidup. Sehingga semakin cukup umur tingkat kematanagan dan kekuatan seseorang akan lebih matang dalam berfikir. Teori Notoatmodjo (2010) juga menyebutkan bahwa semakin bertambahnya usia seseorang maka tingkat pengetahuan akan bertambah pula seiring dengan pengalaman hidupnya. Dengan demikian dengan bertambahnya usia maka signifikan sekali dalam peningkatan pengetahuan responden tentang thalassemia.

Hasil analisis didapatkan bahwa sebagian besar responden keluarga dengan anak Thalassemia di RSUD Pringsewu tahun 2019 yang patuh sebanyak 49 orang $(72,1 \%)$ dan tidak patuh 19 orang $(27,9 \%)$. Menurut peneliti, responden yang patuh membawa anaknya transfusi darah dapat disebabkan oleh pengetahuan dimana pengetahuan yang baik akan mempengaruhi kepatuhan seseorang dalam mengikuti prosedur perawatan. 
Smeltzer \& Bare dalam Pratiwi (2015) mengemukakan salah satu faktor yang mempengaruhi tingkat kepatuhan seseorang adalah faktor demografi yang meliputi usia, jenis kelamin, status, pendidikan dan pengetahuan serta sosioekonomi. Perilaku individu terbentuk melalui tahapan-tahapan pengetahuan, sikap, dan perilaku. Individu yang memiliki pengetahuan yang baik akan menentukan sikap terhadap apa yang diketahuinya, selanjutnya akan terwujud dalam bentuk perilaku. Hal ini sejalan dengan penelitian Octaria (2013), terdapat hubungan kepatuhan ibu/bapak dalam pengobatan anak di Poli Anak RSUD Abdul Moeloek Bandar Lampung didapatkan hasil ada hubungan yang bermakna antara pengetahuan ibu/bapak terhadap pengobatan anak di poli anak RSUD Abdul Moeloek tahun 2013.

\section{SIMPULAN}

Terdapat hubungan yang bermakna antara pengetahuan Thalassemia dengan kepatuhan keluarga membawa anak menjalani transfusi darah di Rumah Sakit Umum Daerah Pringsewu Tahun $2019 p$-value $=0,001(<0,05)$ dan dengan nilai odd ratio $(\mathrm{OR}=7,010)$ yang artinya responden dengan pengetahuan kurang akan beresiko 7 kali tidak patuh membawa anaknya untuk transfusi darah.

\section{SARAN}

Dalam melaksanakan perawatan kepada anak penderita Thalassemia, agar dilakukan secara menyeluruh kepada pasien anak Thalassemia dan kepada keluarga melalui pemberian edukasi, informasi, dukungan emosional sehingga kepatuhan keluarga untuk membawa anak untuk transfusi darah menjadi lebih maksimal.

\section{DAFTAR PUSTAKA}

Dahnil, F., Mardhiyah, A., \& Widianti, E. (2017). Assessment of Supportive Care Needs in Parents of Children with Thalassemia. NurseLine Journal, 2(1), 1-10.

Hockenberry MJ \& Wilson D. (2009). Essentialis of Pediatric Nursing.St.Louis:Mosby.

Marnis, D., Indriati, G., \& Nauli, F. A. (2018) .Hubungan Tingkat Pengetahuan Ibu Dengan Kualitas Hidup Anak Thalasemia. Jurnal Keperawatan Sriwijaya, 5(2), 31-41.

Notoatmodjo, S. (2010). Metodologi Penelitian Kesehatan. Jakarta: Rineka Cipta

Octaria, Y., \& Sibuea, S. (2013). Faktor-Faktor Yang Berhubungan Terhadap Kepatuhan Ibu/Bapak Dalam Pengobatan Tuberkulosis Anak Di Poli Anak Rumah Sakit Abdul Moeloek Bandar Lampung Desember 2012-Januari 2013. Jurnal Majority, 2(4).

Pratiwi, K.D. (2017). Dukungan Sosial Orang Tua dalam Pengobatan dan Perawatan pada Anak penderita Thalasemia.Surabaya: Universitas Airlangga http://repository.unair.ac.id/68249/

Rachmaniah, (2012). Pengaruh Psikoedukasi terhadap Kecemasan dan Koping Oraang Tua dala mMerawat Anak dengan Thalasemia Mayor di RSU Kabupaten Tanggerang Banten.Thesis. Jakarta: Universitas Indonesia http://repository.unair.ac.id/77184/2/TKP. \%2085-18\%20Nis\%20p.pdf

Rahayu, Y, dkk. (2015). Family Support in Compliance Therapy in Patients with Thalassemia in Ciamis District Hospital in 2015. Artikel Penelitian : Mutiara Medika. http://journal.umy.ac.id/index.php/mm/arti cle/view/4451

Rohmah, M. Saputri, N. Bahari J (2019). Effectiveness Of Use Of Nesting On Body Weight, Oxygen Saturation Stability, And Breath Frequency In Prematures In Nicu Room Gambiran Hospital Kediri City. STRADA Jurnal Ilmiah Kesehatan, 9(1), 119-128

Sembiring, S. (2010). Thalasemia.Medan: Morposhlab Ebook. 